UDC $378.1(476)$

\title{
The current state of professional adult education in the Republic of Belarus
}

\author{
Chernychko N.* \\ Kremenchuk Mikhailo Ostrogradskyi National University, Kremenchuk, Ukraine
}

Received: $22.03 .2019 \quad$ Accepted: 15.04 .2019

\begin{abstract}
The article deals with the necessity of studying the peculiarities of additional adult education organization in the Republic of Belarus, which is related to the identification of progressive ideas about additional adult education in Ukraine, improvement of this education area in Ukraine. The legislative sphere of education is analyzed and it has been found out that the Code of the Republic of Belarus on education adoption and its section XIV "Additional Adult Education" was the impetus for the development of this kind of education. The content of twelve types of educational programs is determined and characterized. It is substantiated that adult education is a priority area, integral part of lifetime education system and is one of the important factors of socio-economic development of the country. It is a flexible system that is constantly expanding. The reasons for the development of additional adult education such as introduction of the program of sustainable development of the country, economic growth and others are revealed. The directions of additional adult education elucidation by Belarusian and Ukrainian researchers are determined. The forms of additional adult education organization both traditional and informal are characterized. It has been established that informal education has a rather significant impact on the education as a whole, and on the field of adult education in particular. The mechanisms and ways for the development of both traditional and informal additional adult education in Belarus are highlighted. The main tasks for the development of additional adult education are as follows: improving the system of adult education organization taking into account the changes taking place in society and in development trends of education system of the Republic of Belarus, improving the additional adult education content, developing distance adult education, ensuring compliance of the additional adult education content to the consumers' educational services requirements, developing and improving of teaching and methodological support of educational process, improving statutory and regulatory base of additional adult education, creating the environment for open, flexible education of adult learners.
\end{abstract}

Key words: education of the Republic of Belarus, additional adult education, traditional education, informal education, educational program.

\section{Сучасний стан професійної освіти дорослих у Республіці Білорусь}

Черничко Н. 0.

Кременчуцький національний університет імені Михайла Остроградського, Кременчук, Україна

Анотація. У статті розкрито необхідність дослідження особливостей організації додаткової освіти дорослих Республіки Білорусь, що пов'язано з виявленням прогресивних ідей щодо професійної освіти дорослих України, вдосконаленням даного напряму освіти в Україні. Проаналізовано законодавчу сферу освіти і з'ясовано, що поштовхом до розвитку додаткової освіти дорослих стало прийняття Кодексу Республіки Білорусь про освіту та його розділу XIV «Додаткова освіта дорослих». Визначено й охарактеризовано зміст дванадцяти видів освітніх програм. Обгрунтовано, що додаткова освіта дорослих $є$ пріоритетним напрямком, невід'ємним компонентом системи неперервної освіти та являється одним із важливих чинників соціальноекономічного розвитку країни, являє собою гнучку систему, яка постійно розвивається. Виявлено причини розвитку додаткової освіти дорослих: упровадження програми сталого розвитку країни, економічне зростання тощо. Визначено напрямки висвітлення питання додаткової освіти дорослих у роботах білоруських та українських дослідників. Охарактеризовано форми організації додаткової освіти дорослих: традиційну та неформальну. Встановлено, що неформальна освіта має досить вагомий вплив, як на всю освіту в цілому, так і на ссреру додаткової освіти дорослих. Висвітлено механізми та шляхи розвитку, як традиційної, так і несормальної додаткової освіти дорослих у Білорусі. Визначено основні завдання розвитку додаткової освіти

\footnotetext{
Corresponding Author: Chernychko Nataliia Oleksandrivna. Tel.+38(096) 480-76-73. E-mail: nataliia_chernychko@ukr.net Kremenchuk Mykhailo Ostrohradskyi National University, vul. Pershotravneva, 20, Kremenchuk, Poltava Region, Ukraine, 39600.

Відповідальний автор: Черничко Наталія Олександрівна. Тел. +38(096) 480-76-73. E-mail: nataliia_chernychko@ukr.net Кременчуцький національний університет імені Михайла Остроградського, вул. Першотравнева, 20, м. Кременчук Полтавської обл., Україна, 39600.
} 
дорослих: удосконалення системи організації додаткової освіти дорослих із урахуванням змін, які відбуваються в суспільстві та у тенденціях розвитку системи освіти Республіки Білорусь, удосконалення змісту додаткової освіти дорослих, розвиток дистанційної освіти дорослих, забезпечення відповідності змісту додаткової освіти дорослих вимогам споживачів освітніх послуг, розробка та вдосконалення навчальнометодичного забезпечення освітнього процесу, удосконалення нормативно-правової бази додаткової освіти дорослих, створення умов для відкритого, гнучкого навчання дорослих студентів.

Ключові слова: освіта Республіки Білорусь, додаткова освіта дорослих, традиційна освіта, неформальна освіта, освітня програма.

\title{
Современное состояние профессионального образования взрослых в Республике Беларусь
}

\author{
Черничко Н. А. \\ Кременчугский национальный университет имени Михаила Остроградского, Кременчуг, Украина
}

\begin{abstract}
Аннотация. В статье раскрыта необходимость исследования особенностей организации дополнительного образования взрослых Республики Беларусь, что связано с поиском прогрессивных идей относительно профрессионального образования взрослых Украины, совершенствованием его в Украине. Проанализирована законодательная сфера образования и выяснено, что толчком к развитию дополнительного образования взрослых стало принятие Кодекса Республики Беларусь об образовании и его раздела XIV «Дополнительное образование взрослых». Определено и охарактеризовано содержание двенадцати видов образовательных программ. Обоснованно, что дополнительное образование взрослых является приоритетным направлением, неотьемлемым компонентом системы непрерывного образования и есть одним из важных факторов социально-экономического развития страны, являет собой гибкую систему, которая постоянно развивается. Выявлены причины развития дополнительного образования взрослых: внедрение программы устойчивого развития страны, экономический рост и т. д. Определены направления изучения вопроса дополнительного образования взрослых в работах белорусских и украинских исследователей. Охарактеризованы фрормы организации дополнительного образования взрослых: традиционная и неформальная. Установлено, что неформальное образование имеет достаточно весомое влияние, как на все образование в целом, так и на ссреру дополнительного образования взрослых. Отражены механизмы и пути развития, как традиционного, так и неформального дополнительного образования взрослых в Беларуси. Определены основные задания развития дополнительного образования взрослых: усовершенствование системы организации дополнительного образования взрослых с учетом изменений, которые происходят в обществе и системе образования Республики Беларусь, усовершенствование содержания дополнительного образования взрослых, развитие дистанционного образования взрослых, обеспечение соответствия содержания дополнительного образования взрослых требованиям потребителей образовательных услуг, разработка и совершенствование учебно-методического обеспечения образовательного процесса, усовершенствование нормативно-правовой базы дополнительного образования взрослых, создание условий для открытой, гибкой учебы взрослых студентов.
\end{abstract}

Ключевые слова: образование Республики Беларусь, дополнительное образование взрослых, традиционное образование, несормальное образование, образовательная программа.

\section{Bcmyn}

Сучасні світові глобалізаційні тенденції відображаються на соціально-економічному розвитку кожної країни. Взаємозв'язок і взаємозалежність спостерігається і в освітній сфері у контексті міжнародної стандартизації освіти, європейської інтеграції тощо. Сьогодні у світі зростає значущість професійної підготовки фахівців. Це зумовлює необхідність організації освіти впродовж життя, відкриває можливість працівникам підвищувати свою кваліфікацію чи набувати нових компетенцій, оволодівати новою професією, що користується попитом на ринку праці. Професійна освіта дорослих являється пріоритетним напрямом і $є$ невід'ємним компонентом системи неперервної освіти.

Серед країн пострадянського простору особливий інтерес у ссрері професійної підготовки дорослих викликає Республіка Білорусь, країна, яка разом з Україною входила в СНД, де однією із стратегічних завдань державної економічної політики є переорієнтація економіки на інноваційний шлях розвитку. У вищих навчальних закладах країни успішно функціонують класичний і неформальний підходи у розв'язанні цього питання, широко впроваджуються інноваційні технології навчання. Ця освітня сфера регулюється у країні різними законодавчими актами: Конституцією Республіки Білорусь (від 1994 р.), Законом Республіки Білорусь «Про освіту» (від 29.10.1991р.), Кодексом Республіки 
Білорусь про освіту (від 13.01.2011р.),Постановою Ради Міністрів Республіки Білорусь «Про затвердження Програми розвитку післядипломної освіти в Республіці Білорусь на базі провідних вищих навчальних закладів» (від 17.08.2001р.), Постановою Ради Міністрів Республіки Білорусь «Про окремі питання додаткової освіти дорослих» (від 15.07.2011р.).

Аналіз літературних джерел показав, що питання професійної освіти дорослих висвітлюється переважно у наступних напрямках: загальні проблеми неперервної освіти (С. Вершловський, М. Громкова, В. Ісаєв, Л. Набока, М. Скрипник), робота викладача у системі освіти дорослих та її особливості (Е.Джонс, С. Змєйов, А. Роджерс), особливості складання програм та навчальних матеріалів (Р. Бегнел, Д. Гріффрін, Ф. Рейс). Але на вивченні системи організації професійної освіти дорослих Республіки Білорусь увага науковців не зосереджувалася.

Метою статmі є дослідження особливостей організації професійної освіти дорослих Республіки Білорусь.

\section{II Матеріал і методи дослідження}

Студіювання наукових джерел білоруських дослідників дає можливість наголосити на широкій вживаності терміну «додаткова освіта дорослих», що розглядається як вид освіти, спрямований на професійний розвиток слухача, стажера та задоволення їх пізнавальних потреб [1].

Аналіз праць науковців Білорусі дає можливість виявити основні напрями досліджень та проблеми додаткової освіти дорослих у країні. Так, С. Ф. Назарова [2] вважає, що потреба у додатковій освіті дорослих пояснюється інтенсивними змінами в економіці і суспільному розвитку країни, появою нових технологій, суттєвими демографічними змінами населення, збільшенням вільного часу людей, ростом загальної освіченості населення. Автор відзначає, що навчальний процес будується на принципах системності, обов'язковості, диференційованого підходу та перспективності. Окрім традиційних методів використовуються й активні методи навчання: тренінги, ділові ігри, дискусії за участі спеціалістів та практичних працівників.

Вивченню питання взаємодії закладів освіти («виробниками» освітніх послуг) із роботодавцями («споживачами» освітніх послуг) приділяли увагу Д. О. Конопацький [3] та О. А. Олекс [4]. На їх думку, сучасна система додаткової освіти дорослих буде ефективною за умови її відповідності вимогам замовників кадрів. Щоб цього досягти, слід упровадити заходи, спрямовані на постійне оновлення змісту освітніх програм додаткової освіти дорослих; забезпечення різноманітності, варіативності та гнучкості навчальних планів та освітніх програм; застосування сучасних освітніх технологій. Наголошується, що заклад освіти повинен надавати освітні послуги такої якості, щоб роботодавець бачив результати навчання і був зацікавлений у фахівцях, підготовленими цим навчальним закладом.

І. В. Трусевич та Н. Б. Холджанова [5] зазначають, що в системі додаткової освіти дорослих дуже привабливим як для студентів, так і для роботодавців, $є$ дистанційна система освіти. Використання інноваційних технологій дозволяє студентам-слухачам у зручний час отримувати нові знання i підвищувати здобуту кваліфрікацію. Роботодавців приваблює дистанційне навчання тим, що працівники більше часу будуть знаходитись на своїх робочих місцях.

С. Л. Шаркевич [6] спрямувала свої зусилля на вивчення питання додаткової освіти дорослих людей похилого віку та подальше застосування набутих ними знань.

Ряд науковців (Г. Веремейчик, Д. Карпієвич [7], Є.Д.Тогулева [8]) здійснили ґрунтовне дослідження та аналіз нормативно-правової бази додаткової освіти дорослих.

Вивчення й аналіз досліджень білоруських науковців $[2,3,4,5,7,8]$ дозволяє визначити перспективні напрямки розвитку додаткової освіти дорослих:

1) створення кафедр у провідних вищих навчальних закладах країни для розробки теорії додаткової освіти дорослих;

2) формування у закладах додаткової освіти дорослих компетентного наукового та науковопедагогічного складу, що відповідає рівню міжнародних кваліфрікаційних вимог, які глибоко знають проблеми андрагогіки;

3) розвиток дистанційного навчання;

4) організація гнучкого навчання, сутність якого в тому, що студенти самі визначають для себе зміст навчання, його періодичність, тривалість занять, вибирають час для занять та спосіб навчання; 
5) розвиток відкритого навчання - забезпечення права на навчання усіх, незалежно від віку, соціального статусу чи результатів складених іспитів;

6) співпраця освітніх закладів з підприємствами та роботодавцями;

7) міжнародна співпраця;

8) розробка та вдосконалення навчально-методичного забезпечення освітнього процесу додаткової освіти дорослих;

9) удосконалення нормативно-правової бази додаткової освіти дорослих, узгодження 3 європейськими стандартами.

\section{III Результати}

У Національній доповіді про розвиток системи освіти Республіки Білорусь говориться, що країна увійшла у 21 століття з розвиненою системою освіти, яку визнано стратегічним ресурсом розвитку держави [9]. Система освіти в Білорусі ґрунтується на кращих національних здобутках і традиціях, ураховує світові тенденції у сфері освіти. У ній забезпечується рівність доступу до всіх ступенів освіти, єдність її елементів та вимог, послідовність усіх ступенів навчання.

У Наказі Міністра освіти Республіки Білорусь від 29.11.2017 р. № 742 «Концептуальні підходи до розвитку системи освіти Республіки Білорусь до 2020 року і на перспективу до 2030 року» зазначено, що найважливішою тенденцією освіти за останні десятиліття $€$ перехід від разового отримання кваліфікації на все життя до засвоєння компетенцій (спеціальних, особистісних, суспільних), що сприяють самоосвіті і необхідності навчання та самовдосконалення протягом всього життя [10].

Додаткова освіта дорослих Білорусі $є$ одним із найважливіших чинників соціально-економічного розвитку країни, являє собою гнучку систему, яка постійно розвивається. Вона вирішує задачі забезпечення галузей економіки професійними кадрами необхідного рівня кваліфікації, задовольняє потреби громадян у професійному самовдосконаленні.

Історично додаткова освіта виникла як система підвищення кваліфікації та перепідготовки кадрів у Білорусі виникла близько 50 років тому. На початок 90-их років вона вже нараховувала 136 навчальних закладів, де кожний рік навчалися 400 тисяч студентів. Сьогодні у Білорусі додаткову освіту дорослих пропонує близько 400 закладів освіти, де щорічно навчається біля 500 тисяч студентів.

До 2011 року під додатковою освітою дорослих розуміли:

1) підвищення кваліфікації;

2) перепідготовку;

3) стажування;

4) спеціальну підготовку;

5) курси.

Термін «додаткова освіта дорослих» у нормативних правових актах Білорусі з'явився і почав застосовуватися з 2011 року, після введення в дію Кодексу Республіки Білорусь про освіту і його розділу XIV «Додаткова освіта дорослих» [1] .

Після прийняття Кодексу Республіки Білорусь про освіту додаткова освіта дорослих включає в себе 12 освітніх програм, які показано у таблиці 1.

Згідно статистичного збірника «Освіта в Республіці Білорусь» (2017р.) [11], найпоширенішими напрямками додаткової освіти дорослих є: підвищення кваліфікації (близько 76 \%), перепідготовка (близько 17 \%). На інші види освітніх програм припадає близько 7 \%.

Освітні програми додаткової освіти дорослих здійснюються за допомогою очної та заочної форм навчання.

Реалізують програми додаткової освіти дорослих такі 3ВО Білорусі: академія післядипломної освіти; інститут підвищення кваліфікації і перепідготовки; інститут розвитку освіти; центр підвищення кваліфікації керівних працівників і спеціалістів; центр підготовки, підвищення кваліфрікації і перепідготовки працівників [1].

Найактуальніші сфери додаткової освіти дорослих - техніка і технології, архітектура і будівництво, економіка, управління, сільське господарства [11]. 
Табл. 1. Освітні програми додаткової освіти дорослих Республіки Білорусь

\begin{tabular}{|c|c|c|}
\hline $\begin{array}{l}\text { № } \\
3 / \Pi\end{array}$ & Назва освітньої програми & Зміст освітньої програми \\
\hline 1 & $\begin{array}{l}\text { Підвищення кваліфрікації керівників і } \\
\text { спеціалістів }\end{array}$ & Професійне вдосконалення працівників \\
\hline 2 & $\begin{array}{l}\text { Перепідготовка керівників і спеціалістів, які } \\
\text { мають вищу освіту }\end{array}$ & $\begin{array}{l}\text { Присвоєння нової кваліфрікації на рівні вищої } \\
\text { освіти }\end{array}$ \\
\hline 3 & $\begin{array}{l}\text { Перепідготовка керівників і спеціалістів, які } \\
\text { мають середню спеціальну освіту }\end{array}$ & $\begin{array}{l}\text { Присвоєння нової кваліфікації на рівні спеціальної } \\
\text { освіти }\end{array}$ \\
\hline 4 & Стажування керівників і спеціалістів & $\begin{array}{l}\text { Засвоєння керівниками і спеціалістами нових } \\
\text { методів, технологій та елементів професійної } \\
\text { діяльності }\end{array}$ \\
\hline 5 & $\begin{array}{l}\text { Спеціальна підготовка, яка необхідна для } \\
\text { отримання окремих посад }\end{array}$ & $\begin{array}{l}\text { Поглиблення знань і набуття практичних } \\
\text { професійних навичок особами, які претендують } \\
\text { на отримання посад, для призначення на які } \\
\text { законодавчими актами передбачено проходження } \\
\text { спеціальної підготовки }\end{array}$ \\
\hline 6 & $\begin{array}{l}\text { Підвищення } \\
\text { (службовців) }\end{array}$ & 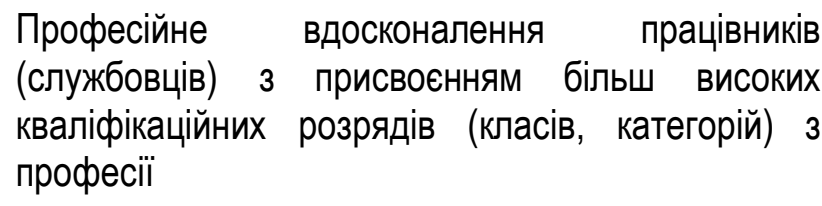 \\
\hline 7 & Перепідготовка працівників (службовців) & $\begin{array}{l}\text { Здобуття профресії особами, які мають іншу } \\
\text { профресію }\end{array}$ \\
\hline 8 & $\begin{array}{l}\text { Професійна } \\
\text { (службовців) }\end{array}$ & $\begin{array}{l}\text { Здобуття професії особами, які не мають } \\
\text { професію }\end{array}$ \\
\hline 9 & $\begin{array}{l}\text { Курси (лекції, тематичні семінари, } \\
\text { практикуми, тренінги, оффіцерські курси та } \\
\text { інші види) }\end{array}$ & $\begin{array}{l}\text { Задоволення пізнавальних потреб у певній сфері } \\
\text { профресійної діяльності або галузі знань }\end{array}$ \\
\hline 10 & Навчання в організаціях & $\begin{array}{l}\text { Формування профресійних навичок, необхідних } \\
\text { для виконання працівниками організацій своїх } \\
\text { посадових обов'язків }\end{array}$ \\
\hline 11 & $\begin{array}{l}\text { Удосконалення можливостей і здібностей } \\
\text { особистості }\end{array}$ & $\begin{array}{l}\text { Моральний, культурний та фізичний розвиток } \\
\text { особистості, формування навичок, необхідних у } \\
\text { повсякденному житті }\end{array}$ \\
\hline 12 & $\begin{array}{l}\text { Підготовка до вступу в заклади освіти } \\
\text { Республіки Білорусь }\end{array}$ & $\begin{array}{l}\text { Вивчення навчальних предметів, які виносяться } \\
\text { на вступ в заклади освіти Республіки Білорусь }\end{array}$ \\
\hline
\end{tabular}


Аналіз наукових праць та нормативної бази дозволяє визначити актуальні завдання додаткової освіти дорослих Білорусі:

1) удосконалення системи перепідготовки та підвищення кваліфікації керівників та спеціалістів закладів освіти із урахуванням змін, які відбуваються в суспільстві, та тенденцій розвитку системи освіти Республіки Білорусь у цілому;

2) забезпечення практико-орієнтованого підходу при реалізації освітніх програм підвищення кваліфікації і перепідготовки кадрів;

3) забезпечення відповідності змісту додаткової освіти дорослих вимогам споживачів освітніх послуг;

4) розвиток дистанційної форми отримання додаткової освіти дорослими;

5) удосконалення науково-методичного забезпечення додаткової освіти дорослих [10].

Для розв'язання зазначених завдань указано такі конкретні способи:

1) удосконалення нормативного правового регулювання діяльності у галузі додаткової освіти дорослих;

2) розробка та затвердження нормативної правової бази для отримання дистанційної додаткової освіти;

3) збільшення практичної частини освітніх програм додаткової освіти дорослих;

4) розширення переліку спеціальностей перепідготовки, в освітні стандарти яких включено стажування або збільшений обсяг годин, передбачених на проходження стажування;

5) розробка та впровадження нових навчальних програм підвищення кваліфікації керівних працівників і спеціалістів у відповідності з інноваційними напрямками та тенденціями розвитку системи освіти;

6) забезпечення проектування освітніх програм додаткової освіти дорослих на основі компетентісного підходу і модульного принципу;

7) оптимізація діяльності навчально-методичних об'єднань у сфері додаткової освіти дорослих шляхом їх інтеграції з навчально-методичними об'єднаннями у сфері вищої освіти;

8) визначення і законодавче закріплення порядку і критеріїв отримання дозволу на реалізацію освітніх програм додаткової освіти дорослих;

9) удосконалення механізму фінансування реалізації освітніх програм додаткової освіти дорослих за пріоритетними напрямками соціально-економічного розвитку суспільства;

10) розвиток різнобічної взаємодії під час реалізації освітніх програм додаткової освіти дорослих [10].

Поряд з класичною, традиційною додатковою освітою дорослих у Республіці Білорусь існує і розвивається неформальна освіта. Неформальна освіта - це будь-яке організоване і систематизоване навчання, яке здійснюється за межами системи формальної освіти. Ця освітня діяльність має певну мету, часові обмеження, інфрраструктурну підтримку і проходить свідомо. У неформальній освіті, як правило, немає такого поняття, як навчальний рік, відсутні загальноприйняті форми освітніх програм [12].

Не зважаючи на свою малочисельність і незначне залучення в даній системі освіти жителів країни (близько 1,2\% населення країни віком від 14 років і старші [13]), неформальна освіта має вагомий вплив як на ссреру додаткової освіти дорослих, так і на всю освіту в цілому.

34 лютого 2011 року у Білорусі діє Асоціація додаткової освіти і просвіти [14]. Це некомерційна організація, яка об'єднує освітні і просвітницькі організації Білорусі. Ї̈̈ діяльність спрямована на координацію дій з розвитку сфери додаткової та неформальної освіти і просвіти.

Асоціація має наступні пріоритети:

- сприяння розвитку організацій сфрери додаткової і неформальної освіти в регіонах Білорусі;

- розробка та впровадження програм підготовки менеджерів, тренерів та фасилітаторів у сфері неформальної освіти;

- відстоювання та просування інтересів організацій, які працюють у сфері неформальної освіти;

- інклюзія у неформальній освіті;

- розвиток та просування концепції громадянської освіти. 
323 червня 2015 року Асоціація додаткової освіти і просвіти $€$ повноправним членом Європейської Асоціації освіти дорослих. Це некомерційна громадська організація, яка об'єднує 123 організації з 42 країн і представляє інтереси близько 60 млн. людей, які навчаються по всій Європі. Ї̈̈ мета - представляти інтереси і підтримувати зв'язок між європейськими організаціями, які працюють у сфері освіти дорослих, просувати ідею розширення доступу до освіти для всіх, а особливо для соціально незахищених груп населення.

Асоціація додаткової освіти і просвіти має наступні найбільш успішні проекти:

- Програма навчальних гуртків;

- Фестиваль навчальних гуртків (2006 р., 2010 р.);

- Навчальний курс «Школа адукаторов»;

- Тиждень неформальної освіти (2005 р., 2006 р., 2007 р., 2009 р., 2011 р.);

- Фестиваль неформальної освіти (2006 р., 2008 р., 2010 р., 2012 р., 2014 р., 2016 р.);

- Фестиваль-презентація громадського арту «Грамадянскасць.ВҮ» (2013р.);

- Журнал неформальної освіти «Адукатар» (видається з 2004 року).

Масштабним і цікавим проектом є Фестиваль неформальної освіти. Він став місцем обговорення актуальних питань та перспектив її розвитку, в тому числі в загальноєвропейському контексті. Фестиваль включає такі заходи: презентації освітніх програм і проектів; майстер-класи; дискусії 3 актуальних питань; цікаві культурні програми; знайомство учасників з потенційними партнерами для реалізації власних ініціатив.

Перший Фестиваль неформальної освіти відбувся 15-17 вересня 2006 року. У роботі Фестивалю взяло участь близько 50 організацій із Білорусі, а також Данії, Германії, Швеції, України та Росії. Професіонали різних галузей зібрались разом, щоб обмінятися досвідом, ідеями, організувати цікаві інтерактивні майданчики, познайомитися з виставкою організацій, освітніх програм і методичної літератури. На Фестивалі відбулися засідання круглих столів з актуальних питань: «Неформальна освіта дорослих для соціально незахищених груп», «Проблеми і перспективи законодавчого забезпечення освіти дорослих», «Освіта та корисність сталого розвитку» та інші [15].

У схожому форматі пройшла кампанія «Навчатися, щоб діяти» (2018 р.) у всіх областях Білорусі. Цей захід був спрямований на популяризацію неформальної та додаткової освіти дорослих. Вона проходила у формі Каравана - організованого руху групи експертів, організаторів та волонтерів. Продемонстровано презентації, майстер-класи, відкриті дискусії, круглі столи. Розглядалися питання розвитку центрів додаткової освіти у сільських регіонах, підвищення кваліфікації тренерів, розроблялися рекомендації з розвитку освіти дорослих у конкретних регіонах.

Необхідно відмітити існування у Республіці Білорусь журналу «Адукатар», в якому знаходять відображення матеріали з проблем неформальної освіти та освіти дорослих [14].

\section{IV Обговорення}

Актуальність проблеми дослідження підтверджується тим, що освіта Республіки Білорусь, а тим більше професійна освіта дорослих вітчизняними педагогами практично не досліджувалася. Також це питання не розглядалося у порівняльному аспекті з Україною. Незважаючи на підписану 18 червня 2001 року Угоду між Міністерством освіти і науки України та Міністерством освіти Республіки Білорусь про співробітництво в галузі освіти [15], фрактично відсутні роботи українських дослідників, які вивчають досвід організації професійної освіти дорослих.

У даному контексті варти згадати такі статті: Л. Лук'янова вивчала питання законодавчого забезпечення освіти дорослих у Республіці Білорусь. Вона зробила аналіз нормативно-правової бази, яка регулює освітню сфреру, дала їй характеристику [16].

О.В. Аніщенко наголошує на важливості вивчення організації додаткової освіти дорослих у Білорусі. Учена розглянула різні підходи до освіти: класичну та неформальну. Значна увага зроблена на виникненні та формуванні додаткової освіти дорослих [17].

Аналіз праць українських дослідників показав, що більшість науковців звернули увагу на вивченні неформальної додаткової освіти дорослих у Республіці Білорусь. Так, О. А. Ісаєва дала характеристику діяльності громадських організацій, спрямованих на розвиток додаткової освіти дорослих [18]. Л. А. Мартинець вказує на роль громадських організацій у забезпеченні неформальної освіти дорослих. 
Наголошує на актуальності вивчення досвіду неформальної освіти дорослих у Білорусі для України [19]. О.В.Василенко зробила ґрунтовний загальний історичний аналіз розвитку неформальної освіти дорослих у зарубіжних країнах [20].

У даній статті для досягнення поставленої мети застосовано загальнонаукові методи дослідження: аналіз законодавчої бази додаткової освіти дорослих Республіки Білорусь, наукових праць білоруських та українських дослідників для визначення завдань професійної підготовки фахівців цього процесу, особливостей організації, основних напрямків розвитку.

\section{V Висновки}

Таким чином, досліджено стан та особливості організації додаткової освіти дорослих Республіки Білорусь. З'ясовано, що програми додаткової освіти дорослих реалізують наступні 3ВО Білорусі: академія післядипломної освіти; інститут підвищення кваліфікації і перепідготовки; інститут розвитку освіти; центр підвищення кваліфікації керівних працівників і спеціалістів; центр підготовки, підвищення кваліфікації і перепідготовки працівників.

Освіта у Білорусі розглядається як один із головних пріоритетів державної політики і має на меті сфрормувати вільну, творчу, інтелектуально і фізично розвинену особистість [10]. Білорусь $є$ країною, де спостерігається стабільний ріст економіки, що актуалізує необхідність підготовки фахівців, здатних швидко реагувати на зміни в зовнішньому і внутрішньому середовищі, бути гнучкими у прийнятті нестандартних рішень. Додаткова освіта дорослих має можливість вирішувати дані завдання, забезпечуючи галузі народного господарства висококваліфікованими професійними кадрами.

у наступних наукових розвідках вважаємо за доцільне продовжити дослідження організації додаткової освіти дорослих Республіки Білорусь, зробивши акцент на аналізі навчально-методичного забезпечення освітнього процесу.

\section{Бібліографічні посилання}

[1] Кодекс Республики Беларусь об образовании от 13.01.2011 г. № 243-3. Минск. URL: http://kodeksy.by/kodeks-obobrazovanii (дата звернення: 17.04.2019).

[2] Назарова С. Ф. Высшее и дополнительное образование в Беларуси в условиях инновационного развития. Инновационные процессы и корпоративное управление : материалы IV Междунар. научн.-практ. конфер. (Минск, 1530 марта 2012 г.) Минск: УО ФПБ «Международный университет «МИТСО». 2012. С. 323-330.

[3] Конопацкий Д. А. Дополнительное образование взрослых: тенденции развития = Quality improving qualification and retraining for adults. Инновации в системе непрерывного технического образования : материалы Республиканской научн.-практ. конфер. (Минск, 29-30 мая 2014 г.). Минск : БНТУ, 2014. С. 5-10.

[4] Олекс О.А. Дополнительное образование взрослых в Республике Беларусь: проблемы развития. Современные тенденции в дополнительном образовании взрослых : материалы II междунар. науч.-метод. конф. (Минск, 27-28 нояб. 2014 г.). Минск, 2014. С. 110-117.

[5] Трусевич И. В., Холджанова Н. Б. Инновационные технологии в дополнительном образовании взрослых. Молодежь для науки и кооперации: разработки и перспективы : сб. науч. ст. IV международного форума молодых ученых I редкол. : Н. А. Сныткова [и др.]. Гомель: БТЭУПК, 2015. 300 с.

[6] Шаркевич С.Л. Дополнительное образование как механизм социально-педагогической поддержки людей пенсионного воззраста. Современные тенденции в дополнительном образовании взрослых : материалы II междунар. науч.-метод. конф. (Минск, 27-28 нояб. 2014 г.). Минск : РИВШ, 2014. 182 с.

[7] ВеремейчикГ., Карпиевич Д. Развитие образования взрослых в Беларуси: к вопросу о нормативно-правовом регулировании. Адукатар. 2006. № 2 (8). С. 15-23.

[8] Тогулева Е. Д. Состояние и перспективы развития дополнительного образования взрослых в Республике Беларусь. Наука - образованию, производству, экономике : материалы XVII (64) Региональной научн.-практ. конфер. преподавателей, научн. сотрудников и аспирантов (Витебск, 14-15 марта 2012 г.) : в 2 т. Витебск: ВГУ имени П. М. Машерова, 2012. Т. 1. С. 397-398.

[9] Национальный доклад о развитии системы образования Республики Беларусь. 2006. URL: http://do.gendocs.ru/docs/index-575.html (дата звернення: 17.04.2019).

[10] Концептуальные подходы к развитию системы образования Республики Беларусь до 2020 года и на перспективу до 2030 года от 29.11.2017 № 742. URL: http://gimnaziya3.by/klassnomu-rukovoditelyu/1533-kontseptualnye-podkhody-krazvitiyu-sistemy-obrazovaniya-respubliki-belarus-do-2020-goda-i-na-perspektivu-do-2030-goda (дата звернення: 17.04.2019).I

[11] Образование в Республике Беларусь. Статистический сборник. Минск, 2017. 220 с. 
[12] Карпиевич Д. В. Неформальное образование в Беларуси: из опыта деятельности негосударственных некоммерческих организаций. Образование через всю жизнь: непрерывное образование в интересах устойчивого развития : материалы 11-й междунар. конф. (Минск, 27-28 сентября 2013 г.) Минск, 2013. Вып. 11. Ч. ІІІ. С. 61-65.

[13] Корж В., Жураковский В., Ображей О., Аношко Е. Состояние гражданского образования в Республике Беларусь. Минск, 2013.73 с.

[14] Асацыяцыя дадатковай адукацыі і асветы (Асоциация дополнительного образования и просвещения). URL: http://adukatar.net/ (дата звернення: 17.04.2019).

[15] Угода між Міністерством освіти і науки України та Міністерством освіти Республіки Білорусь про співробітництво в галузі освіти від 18 червня 2001 p. URL : https://zakon.rada.gov.ua/laws/show/112_039 (дата звернення: 17.04.2019).

[16] Лук'янова Л. Законодавче забезпечення освіти дорослих: зарубіжний досвід. Українська асоціація освіти дорослих. Київ : ТОВ «ДКС-Центр», 2017. С.47-49.

[17] Аніщенко О.В. Сучасна освіта дорослих: досвід Республіки Білорусь. Нові технології навчання: наук. зб. I О. П. Гребельник (гол. ред.). Київ: Ін-т інноваційних технологій і змісту освіти МОН України, 2009. № 59. Ч. ІІ. С. 108112.

[18] Ісаєва О.А. Щодо питання організації неформальної освіти дорослих у Білорусі: зб. наук. пр. професорськовикладацького складу ДонНУ імені Василя Стуса за 2015-2016 рр. Т. 2. Вінниця, 2017. 190 с.

[19] МартынецЛ.А., Исаева О.А. Неформальное образование взрослых в Беларуси. Современные тенденции 8 дополнительном образовании взрослых: материалы III Междунар. науч.-метод. конф. (Минск, 21 окт. 2016 г.) : в 2 ч. Минск : РИВШ, 2016. Ч. 1. С. 151-154.

[20] Василенко О. В. Розвиток дорослих у неформальній освыіі (зарубіжний досвід) Особистісний і професійний розвиток дорослих: теорія і практика: [монографія] / за ред. О. В. Аніщенко. Київ: ІПООД НАПН України, 2016. 354 с.

\section{References}

[1] Kodeks Respubliki Belarus ob obrazovanii ot 13.01 .2011 g. \# 243-3. Minsk. URL: http://kodeksy.by/kodeks-ob-obrazovanii (data zvernennya: 17.04.2019). [in Russian].

[2] Nazarova, S. F. (2012). Vyisshee i dopolnitelnoe obrazovanie $v$ Belarusi $v$ usloviyah innovatsionnogo razvitiya. Innovatsionnyie protsessyi i korporativnoe upravlenie : materialyi IV Mezhdunar. nauchn.-prakt. konfer. (Minsk, 15-30 marta 2012 g.) Minsk: UO FPB «Mezhdunarodnyiy universitet «MITSO». 323-330. [in Russian].

[3] Konopatskiy, D. A. (2014). Dopolnitelnoe obrazovanie vzroslyih: tendentsii razvitiya = Quality improving qualification and retraining for adults. Innovatsii $v$ sisteme nepreryivnogo tehnicheskogo obrazovaniya : materialyi Respublikanskoy nauchn.prakt. konfer. (Minsk, 29-30 maya 2014 g.). Minsk : BNTU. 5-10. [in Russian]

[4] Oleks, O. A. (2014). Dopolnitelnoe obrazovanie vzroslyih v Respublike Belarus: problemyi razvitiya. Sovremennyie tendentsii v dopolnitelnom obrazovanii vzroslyih : materialyi II mezhdunar. nauch.-metod. konf. (Minsk, 27-28 noyab. 2014 g.). Minsk. 110-117. [in Russian].

[5] Trusevich, I. V., Holdzhanova, N. B. (2015). Innovatsionnyie tehnologii v dopolnitelnom obrazovanii vzroslyih. Molodezh dlya nauki i kooperatsii: razrabotki i perspektivyi : sb. nauch. st. IV mezhdunarodnogo foruma molodyih uchenyih. Gomel: BTEUPK. 300. [in Russian].

[6] Sharkevich, S. L. (2014). Dopolnitelnoe obrazovanie kak mehanizm sotsialno-pedagogicheskoy podderzhki lyudey pensionnogo vozzrasta. Sovremennyie tendentsii v dopolnitelnom obrazovanii vzroslyih : materialyi II mezhdunar. nauch.metod. konf. (Minsk, 27-28 noyab. 2014 g.). Minsk : RIVSh. 182. [in Russian].

[7] Veremeychik, G., Karpievich, D. (2006). Razvitie obrazovaniya vzroslyih v Belarusi: k voprosu o normativno-pravovom regulirovanii. Adukatar. \# 2 (8), 15-23. [in Russian].

[8] Toguleva, E. D. (2012). Sostoyanie i perspektivyi razvitiya dopolnitelnogo obrazovaniya vzroslyih v Respublike Belarus. Nauka - obrazovaniyu, proizvodstvu, ekonomike : materialyi XVII (64) Regionalnoy nauchn.-prakt. konfer. prepodavateley, nauchn. sotrudnikov i aspirantov (Vitebsk, 14-15 marta 2012 g.) : v 2 t. Vitebsk: VGU imeni P. M. Masherova, T. 1. 397-398. [in Russian].

[9] Natsionalnyiy doklad o razvitii sistemyi obrazovaniya Respubliki Belarus. 2006. URL: http://do.gendocs.ru/docs/index575.html (data zvernennya: 17.04.2019). [in Russian].

[10] Kontseptualnyie podhodyi k razvitiyu sistemyi obrazovaniya Respubliki Belarus do 2020 goda i na perspektivu do 2030 goda ot 29.11.2017 \# 742. URL: http://gimnaziya3.by/klassnomu-rukovoditelyu/1533-kontseptualnye-podkhody-k-razvitiyu-sistemyobrazovaniya-respubliki-belarus-do-2020-goda-i-na-perspektivu-do-2030-goda (data zvernennya: 17.04.2019). [in Russian].

[11] Obrazovanie v Respublike Belarus. (2017). Statisticheskiy sbornik. Minsk, 220. [in Russian].

[12] Karpievich, D. V. (2013). Neformalnoe obrazovanie v Belarusi: iz opyita deyatelnosti negosudarstvennyih nekommercheskih organizatsiy. Obrazovanie cherez vsyu zhizn: nepreryivnoe obrazovanie $v$ interesah ustoychivogo razvitiya : materialyi 11-y mezhdunar. konf. (Minsk, 27-28 sentyabrya 2013 g.) Minsk. Vyip. 11. Ch. III. 61-65. [in Russian].

[13] Korzh, V., Zhurakovskiy, V., Obrazhey, O., Anoshko, E. (2013). Sostoyanie grazhdanskogo obrazovaniya v Respublike Belarus. Minsk, 73. [in Russian].

[14] Asatsyiyatsyiya dadatkovay adukatsyil I asvetyi (Asotsiatsiya dopolnitelnogo obrazovaniya i prosvescheniya). URL: http://adukatar.net/ (data zvernennya: 17.04.2019). [in Belarus].

[15] Ugoda mlzh MInlsterstvom osvlti I nauki UkraYini ta MInlsterstvom osvlti Respubllki Bllorus pro splvrobltnitstvo v galuzl osvlti vld 18 chervnya 2001 r. URL : https://zakon.rada.gov.ua/laws/show/112_039 (data zvernennya: 17.04.2019). [in Ukrainian]. 
[16] Luk'yanova, L. (2017).Zakonodavche zabezpechennya osvlti doroslih: zarublzhniy dosvld. UkraYinska asotslatslya osvlti doroslih. KiYiv : TOV «DKS-Tsentr». 47-49. [in Ukrainian].

[17] Anlschenko, O. (2009). Suchasna osvlta doroslih: dosvld Respubllki Bllorus. Novl tehnologlYi navchannya: nauk. zb. I O. P. Grebelnik (gol. red.). KiYiv: In-t Innovatslynih tehnologly I zmlstu osvlti MON UkraYini. \# 59. Ch. II. 108-112. [in Ukrainian].

[18] Isaeva, O. A. (2017).Schodo pitannya organlzatsIYi neformalnoYi osvlti doroslih u Bllorusl: zb. nauk. pr. profesorskovikladatskogo skladu DonNU Imenl Vasilya Stusa za 2015-2016 rr. T. 2. VInnitsya. 190. [in Ukrainian].

[19] Martyinets, L. A., Isaeva, O.A. (2016). Neformalnoe obrazovanie vzroslyih $\vee$ Belarusi. Sovremennyie tendentsii $v$ dopolnitelnom obrazovanii vzroslyih: materialyi III Mezhdunar. nauch.-metod. konf. (Minsk, 21 okt. 2016 g.) : v 2 ch. Minsk : RIVSh. Ch. 1. 151-154. [in Russian].

[20] Vasilenko, O. V. (2016). Rozvitok doroslih u neformalnly osvyill (zarublzhniy dosvld) Osobistlsniy I profeslyniy rozvitok doroslih: teorlya I praktika: [monograflya]. KiYiv: IPOOD NAPN UkraYini. 354. [in Ukrainian].

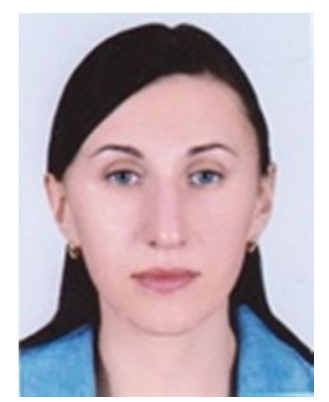

Черничко Наталія Олександрівна.

Аспірант кафедри психології, педагогіки та філософії,

Кременчуцький національний університет імені Михайла Остроградського,

вул. Першотравнева, 20, м. Кременчук Полтавської обл., Україна, 39600.

Тел. +38(096) 480-76-73. E-mail: nataliia_chernychko@ukr.net

\section{Chernychko Nataliia Oleksandrivna.}

Postgraduate Student of Psychology, Pedagogy and Philosophy Department,

Kremenchuk Mykhailo Ostrohradskyi National University,

vul. Pershotravneva, 20, Kremenchuk, Poltava Region, Ukraine, 39600.

Tel.+38(096) 480-76-73. E-mail: nataliia_chernychko@ukr.net

ORCID: 0000-0002-4737-0952

Citation (APA):

Chernychko N. (2019). The current state of professional adult education in the Republic of Belarus. Engineering and Educational

Technologies, 7 (2), 80-89. doi: https://doi.org/10.30929/2307-9770.2019.07.02.08

\section{Цитування (ДСТУ 8302:2015):}

Черничко Н. О. Сучасний стан професійної освіти дорослих у Республіці Білорусь / ннженерні та освітні технологї. 2019. Т. 7. № 2. C. 80-89. doi: https://doi.org/10.30929/2307-9770.2019.07.02.08

Обсяг статmі: сторінок-10 ; умовних друк. аркушів - 1,448. 